\title{
The Impact of European Integration on the Formation of a New Monetary Law: The Case of Serbia
}

\author{
MARKo DimitriJeVić*
}

\begin{abstract}
This paper identifies and analyses the impact of European integration on the structure and characteristics of the modern monetary law, with a special emphasis on the characteristics of the monetary system of Serbia. A particular problem with monetary sovereignty analysis is the external effects, which are reflected in the EMU attempt to expand its authority over the territory of the Member States. This is particularly evident in the case of the candidate countries, which must harmonize their financial legislations with the acquis communautaire. Monetary policy is fully centralized at the European Union level, so Serbian lawmakers must make the necessary derogations of monetary standards in order to facilitate future accession to EMU - primarily the provisions Law of Central Bank, Law on Public Debt Management and the Foreign Exchange Act.
\end{abstract}

Keywords: monetary law, EU, monetary sovereignty, Serbia.

\section{INTRODUCTION}

The recent economic crisis has highlighted that the legal mechanisms of fiscal policy coordination of EU Member States are slow in practice due to the inability to balance the interests of different States, which are not willing to delegate any components of their fiscal and financial sovereignty. The creation of a monetary union is not a goal in itself, but a tool for creation of fundamental objectives of the European Community. ${ }^{1}$ The Treaty of Maastricht has shown that in creating a monetary union a conservative concept (in order to join the union it is necessary to respect the fiscal rules) over liberal views prevailed, whereas the concept of monetary union implies the introduction of the hard budgeting principles, which prohibits the financing of budget deficits by loans from the Central Bank. ${ }^{2}$

Experiences with the coordination of fiscal policies in this area show that, at a certain point, there is a tendency to rescue failing States and violating a no-bailout clause, i.e. prohibition of mutual financing of member states of the Union. Many authors point to the negative consequences of the existence of mutual responsibility for public debt management because it reinforces the problem of moral hazard (conscious indulging in behavior that increases the probability of risk occurrence) and encourages the disorderly management of public finances, the main reason for the failure of national fiscal and monetary policies coordination. It is also evident that the global economic crisis highlighted the weaknesses of the entire international financial architecture for applying financial standards in order to

* PhD, Teaching Assistant, Faculty of Law, University of Niš, 18000 Niš, Serbia. E-mail: markod@1985prafak.ni.ac.rs. This paper is a result of the research conducted within the project 'Harmonisation of Serbian Law with EU Law (2013-2018)' carried out by the Faculty of Law, University of Niš

1 Golubović (2007) 49.

2 Babić (2011) 401. 
avoid the consequences of the great recession (by eliminating systemic risks) and the convocation of special organs in national legislation, which would encourage respect for those standards. ${ }^{3}$

The paper is structured so that the first part shows the settings and features of modern monetary European law and the role of the convergence criteria in its shaping, while the second part of the paper points to the institutional framework of monetary law in Serbia in the context of European integration. The major challenges in this sphere of law will be highlighted by applying a logical method, the comparative, the axiological method and statistical analysis. Potential guidance for Serbian monetary lawmakers will also be offered.

\section{CONTEMPORARY EUROPEAN MONETARY LAW}

The basic principles of European monetary law must be taken into consideration for the justification of the existence of the monetary union. In the structure of the monetary law it is common to make a distinction between areas in which the Union has full authority and reporting as the sole titular of rights (individually bringing financial and legal decisions according lex monetae) and the jurisdiction in which the Member States (individually or collectively by concluding multilateral agreements) make decisions in the area of monetary policy (lex contractus). The monetary law of EU, according to the principle of the lex monetae, implies the totality of legal norms which in the monetary sphere determine the character of the public debt. ${ }^{4}$ Member states of the Union enjoy a contractual freedom when concluding agreements which determine the currency unit in which the public debt will be denominated, but once the monetary unit is selected, the Members automatically become the subjects under the monetary law norms influence of the country whose currency is selected. Standard monetary law should provide a clear definition of the currency units and specify its values. ${ }^{5}$

During the creation of the monetary union, the member states had their monetary sovereignty delegated to the European Central Bank, which means that the monetary EU law is directly applicable and does not exist in parallel with national monetary legislation of the member states. Procedural sources of EU law are present in communitarian acts and enjoy absolute supremacy. In this respect, article 123 of the Treaty on the EU, which regulated the transition to the new single currency and established legal mechanisms for implementation of these principles in the field of soft law, is very important. ${ }^{6}$ It must be noted that case law, legal jurisprudence and judicature of courts have made a considerable contribution in shaping the concept of monetary sovereignty.

A particular problem with the analysis of monetary sovereignty are the external effects, which are reflected in the subjects' attempt (in this case the EMU) to extend its authority over the territory of the member states (in particular, State candidates who have to harmonize financial regulations with acquis communautaire) in the absence of a norm of international public law that it would prevent. ${ }^{7}$ The transfer of jurisdiction for the conduct of monetary policies with the national to a communitarian level of jurisdiction gives these standards a special dimension as Member states have to face the costs and benefits of the

\footnotetext{
3 Giovanoli (2000) 3-10.

4 Wahlig (2000) 121-22.

5 De Lapasse (2005) 235-44.

6 Louis (2000) 5-34.

7 Gianviti (2005) 13.
} 
existence of the monetary union. Costs are reflected in the loss of independence of the Central Bank as the high monetary institutions in the conduct of monetary-credit policy and the possibility of using the exchange rate as an instrument for alleviating economic shocks. In contrast, the benefits of common monetary policy are reflected in lower economic costs and better integration of markets. ${ }^{8}$

A large number of authors believe that the main cause of the financial crisis that erupted in 2008 was the existence of legal gaps in the EU Treaty. ${ }^{9}$ In this regard, it is necessary to review the fulfillment of the conditions for the successful functioning of the single currency as economic (if the economies of the EU Member States are mutually consistent enough) and legal (the EU's ability to defend the purchasing power of the euro) conditions.

In the financial literature, the opinions of theoreticians about the justification of the existence of the economic Union are divided. Mundell, who is considered the founder of the theory of optimum currency areas, points out that an essential condition for defining unified currency areas is the physical mobility of capital and manpower and that the mobility of production factors only has alternative means of economic adjustment. ${ }^{10}$ Feldstein also considers that the EU does not meet any requirements for a successful introduction of the single currency because the member states have a different structure of GDP (dependent on oil imports) and the mobility of the manpower is determined by overcoming language and cultural barriers. ${ }^{11}$ The legal requirement for joining the European monetary union, which relates to the fulfilment of the convergence criteria stipulated by the Maastricht Treaty (provisions on the amount of public debt, inflation, exchange rates and long-term interest rates), is difficult to maintain in practice and requires review. ${ }^{12}$ The euro is the only currency in the world that does not have legal protection as a symbol of sovereignty as the agreement on the EU Constitution was not successfully passed in a referendum. The European Central Bank has all of the powers similar to supranational monetary institutions but it does not state power and there are no legally valid sanctions for violation of its decision, i.e. deviations from the predicted convergence criteria. In terms of the crisis, it became clear that the stability of public finance can be provided by cumulative use of fiscal transfer and evolution of the role of the Central Bank, which must carry out the function as the bank of the last resort. ${ }^{13}$ Cumulative fulfillment of legal and economic convergence conditions is equally important, in the author's opinion, for the successful functioning of the eurozone in terms of creating a global economic system and monetary stability, which occurs as one of the most important public goods in addition to an efficient judiciary; internal and external security; the health of citizens; and preserving natural assets.

\section{THE ROLE OF THE CONVERGENCE CRITERIA IN SHAPING THE EUROPEAN MONETARY LAW}

The eurozone crisis was not just an internal problem for members of the Monetary Union because it had an external dimension, which implied legal obligations of countries of the euro-zone in accordance with the international monetary law in the context of the

\footnotetext{
8 De Grauwe (2003) 110-11.

9 Hermann (2013) 26-40.

10 Mundell (1961) 657-65.

11 Feldstein (2013) 11.

12 Siekmann (2011) 5-6.

13 Lastra (2015) 126-27.
} 
preservation of monetary stability. ${ }^{14}$ The relationship between supranational and national law is crucial for determining the transparent concept of European monetary law, which will be socially accepted. The necessary demarcation in the meaning of the terms of monetary union and the monetary system must be highlighted. Namely, the monetary system exists when states are linking their currencies that function as unique in relation to the currencies of other countries. The monetary union between countries requires the existence and the use of the single money (de jure EMU) or unconditional establishment of foreign currency exchange rates of countries that participate in economic monetary union together with the free movement of goods and other production factors, which is de facto EMU. ${ }^{15}$

The Maastricht Treaty set out the rules for joining a monetary union called the convergence criteria. While there is no ubiquitous definition of convergence criteria, it is generally accepted that there are views of mutual convergence of certain macroeconomic criteria that contribute to macroeconomic stability in economically integrated areas. ${ }^{16}$ Convergence may occur as ex-ante (previous nominal convergence) or ex-post (subsequent nominal or real if including convergence of economic cycles or the systems of central banks). The concept of convergence is close to the concept of cohesion, which is used to define a set of Community policies aimed at reducing income disparities between certain (developed and less developed) countries. Modern monetary law stands on the view that, at the fulfilment of criteria, it must take care of fulfillment with the conditions relating to the degree of financial and market integration; the development of the balance of payments; flows of foreign direct investment; labour costs; and other factors. In practice, there is a clear distinction between legal and economic convergence criteria. ${ }^{17}$ The legal criteria of convergence relate to the harmonization of national legislation with the acquis of the Union. Economic criteria of convergence do not concern the establishment of the single currency area. They represent conditions for achieving an optimal currency area microeconomic nature, in terms of the flexibility of wages and prices, as well as the mobility of production factors. Economic convergence criteria relate to the rate of inflation, budget deficit, public debt, nominal interest rates and the exchange rate. So they, in terms of price convergence, regulate that the inflation rate measured by the index of consumer price must not exceed $1.5 \%$ of the average inflation in the three countries with the lowest inflation. Fiscal convergence means that the budget deficit must not exceed 3\% of GDP, while the convergence of public finances means that public debt must not exceed $60 \%$ of GDP in a given member state. Convergence of exchange rates of the currencies of variance requires respect of $\pm 1.5 \%$, which provides a mechanism of foreign exchange during the two years before the start of the third stage in the creation of the European Monetary Union. Convergence of interest rates indicates that the nominal interest rate must not be more than $2 \%$ in relation to the interest rate of the three best performers with the lowest interest rates.

The Treaty of Maastricht established convergence criteria in the fiscal policies that are needed to ensure the sustainability of public finances - namely, the defined fiscal policy that the budget deficit must not exceed $3 \%$ of the gross domestic product and public debt should not exceed $60 \%$ of the domestic gross product expressed in market prices. The fiscal rules include the 'regulated by law, long-term, numerically expressed constraints of budgetary

\footnotetext{
14 Feibelman (2012) 101-05.

15 Jovanović (2007) 79-81.

16 Prokopijević (2007) 79-80.

17 Cerovac et al. (2010) 34.
} 
aggregates which refer to the height of the public debt, budget deficits and public expenditure and revenues'. ${ }^{18}$

The Stability and Growth Pact sets out in detail the fiscal rules laid down by the Treaty of Maastricht by which monetary union members must abide by. The problems culminated when the European Council abolished the procedure that applies in the case of excessive deficits in Germany and France. This is why the European Commission turned to the European Court of Justice as the question was brought up in equal treatment of all Member States. The Stability and Growth Pact was quickly reformed in 2005, and it predicts that the excessive deficit procedure is absent in the case of negative growth rates (lower rates) and also introduces the legal standard of other relevant factors that condition the decision on applying the procedures in case of excessive budget deficits. ${ }^{19}$ It is the expenditure for research and development, capital expenditures, the international solidarity, which significantly relativised the uniqueness of the original document. ${ }^{20}$ In addition, the reform of the Pact is marked and an extension of the deadlines for the correction of the budget deficit, as well as the terms on which the Council shall take a decision on imposing sanctions are defined.

However, the practice has shown that this reformed Stability Pact was not able to perform the needed influence on overall fiscal discipline over a longer period, hence the current need for its optimal renewal. Namely, how, at a time of crisis, were tumbled EU member states not allowed to be rescued (it was forbidden under article 125 of the Maastricht treaty) and then come to establish a European Agency for financial stability. Soon after, the creation of the European Stability Mechanism marked the change of the hard law, in particular art. 136 (3) of the EU Treaty. Interestingly, the European Court of Justice ruled (case C-370/12, Pringle vs. Ireland) that by constitution of this coordinating mechanism, there has been no breach of the law because its legal nature is such that the measures of financial assistance are understood as 'your measure', rather than as measures aimed at cleaning up the consequences of the public debt (which has created a form of transfer of the Union). These inadequate results in the implementation of the Stability and Growth Pact result from the absence of credibility in the implementation of sanctions imposed on States, which required adequate institutional reform. ${ }^{21}$

The costs of monetary union arise when member states abandon their national currencies and leave a significant instrument of economic policy regarding mitigation of consequences of economic disruption. In terms of complete monetary union, the central bank loses its real power to affect change in currency prices through devaluation measures or revaluation, to determine the mass of money in circulation and to alter short-term interest rates. ${ }^{22}$ The costs of monetary union can be on a microeconomic level while the benefits are on the macroeconomic level. Krugman notes that the analysis of the benefits and costs of monetary union established the trade-off between macroeconomic flexibility and microeconomic efficiency. ${ }^{23}$

Benefits for countries that join the monetary union are reflected in eliminating uncertainties and risks regarding the movement of the exchange rate. The introduction of

18 Schaecter et al. (2012) 10-12.

19 Dutzler \& Hable (2005) 1-6.

20 Mortensen (2013) 11-14.

21 Lastra (2007) 265-70.

22 De Grauwe (2003) 29-30.

23 Krugman (1993) 3-4. 
the euro as the uniform European currency has left its mark on the world's currency and caused a change in the international economic and financial relations. World currency issuer enjoys great benefits of achieving emission profit. Certainly, a common monetary policy of member states' monetary union vis-à-vis with non-member countries brings political power and economic reputation. The supporters of the establishment of the monetary union saw a much needed political and legal mechanism and European monetary entity that would be competitive the U.S. dollar in the world market. The introduction of the single currency was expected to boost trade exchange and cooperation between member states and indirectly contribute to greater transparency of prices. Greater price transparency and competition means growth, which is in the interest of protecting the rights of consumers. The elimination of price instability would mean improved efficiency of allocated price mechanisms which increases the total social welfare. ${ }^{24}$ The main advantage of participation in the monetary union is increasing the degree of credibility in the implementation of monetary policy, when viewed from a legal point of view. The existence of differences in legal systems can be very relevant in the analysis of the cost of monetary union, as well as other differences that have the political, historical, geographical and institutional background. The real estate markets regulations and tax legislation represent a major challenge along the way.

\section{THE INSTITUTIONAL FRAMEWORKS OF THE NEW MONETARY LAW IN SERBIA: EUROPEAN INFLUENCE}

Harmonisation of domestic legislation with the acquis communautaire is gaining special importance in Serbia's journey towards inclusion in the EU. The formatting of the optimal framework of monetary law is only possible with the determination of the essential elements of the co-ordination mechanisms of communitarian economic policy.

The prerequisite of successful compliance of the domestic monetary system with the provisions of the acquis communautaire is formulating a consistent, realistic, transparent, quantitative program, and stabilization, and development of economic policy as well. In this regard, it is important that the Government take the responsibility completely to implement established objectives of the concept of economic policy for the duration of its mandate, where in case of lack of the successful realization of the future of real conditions in the domestic economy that meant the application of sanctions in the form of termination of the mandate and calling new elections. Such stringent sanctions are necessary because the question of European integration requires the full commitment of the main subjects of economic policy, i.e., the government, parliament, central bank, and establishing their coherent cooperation with other operators, starting with the trade unions and economic chambers, through companies in the public sector, through various associations of citizens such as the association of taxpayers, association for environmental protection, consumer associations and others. If the concept of domestic economic policy does not meet all of the following conditions and does not enjoy the confidence of the citizens, the process of coordination will remain just an empty letter, which loses its justification and purpose.

Serious intentions towards economic recovery and progress, domestic subjects have been showed by adopting a Fiscal strategy for 2015 - the two-year projections are largely consistent with the basic function of the monetary law. Thus, in the policy objectives of economic policy it insists on achieving macroeconomic stability through the implementation 
of fiscal consolidation and elimination of obstacles to the growth of economic competitiveness of comprehensive structural reforms. However, taking into account the failures in the implementation of the objectives of the previous fiscal strategy, the implementation of identified measures and instruments become imperative that strategy itself would not become a tabula rasa. After formulating the effective concept of economic policy, it may take steps on the approximation of monetary-credit and fiscal policies as its two most important subsystems, which shape the solution in monetary law.

In the field of monetary policy, a requirement of successful monetary integrations is meeting the legal and economic convergence system established by the Maastricht Treaty and the Stability and Growth Pact. The complete centralization of monetary policy at the EU level requires the subjects of economic policy to make the necessary modifications in the field of monetary law that will facilitate future accession to the EMU. It requires changing the normative regulation of the valid exchange rate, which form a regime of the flexibly regulated exchange rate and must transform into hard exchange regime. Implementation of such a goal can be associated with a number of difficulties, which are reflected in the fact that, in the introduction of the euro as the official currency, the Central Bank loses the ability to use instruments of foreign policy in limiting and annulling consequences of the economic and financial crisis. On the other hand, the domestic economic policy could achieve the benefits that are reflected in deeper and piercing market integration and lower costs transactions after joining the EMU. Implementation of these conditions open dilemmas that were present during the accession of all member states to the uniform currency area where the decision on the choice was always determined by tradeoffs, i.e., exchange costs for benefits. Taking into account the possibility of accessing the uniform market of the Union and all the benefits it carries, domestic subjects of economic policy should respect the experience of other member states and follow their path of monetary integration.

During the session on August 30th 2006, the Monetary Board of the National Bank of Serbia adopted a new measure and approved new principles of implementing monetary policy aimed at the achievement of the objectives in terms of inflation. The permanent orientation of Serbian monetary policy should represent a gradual move on the real exchange rate and should be in function of increasing production, employment, and the competitiveness of the economy and reducing the deficit in foreign trade exchange. The National Bank of Serbia, with its interventions, spent a lot of money of foreign exchange reserves in order to maintain fiscal stability. Factors that would determine the range of these interventions in the coming period are the influx of foreign direct investments, the risk of the region and economic recovery in the EU.

The National Bank of Serbia is the institution that establishes a very rich communication not only with representatives of other state bodies and financial institutions but also with the citizens who can express their suggestions and opinions. ${ }^{25}$ However, the National Bank is a supreme monetary institution and the main subject of Serbia's monetary law has very clear objectives and instruments in terms of maintaining macroeconomic stability and exchange rate management. For this reason, any outside compromises and pressures cannot be tolerated, because only with full independence from the executive authorities can these targets achieve to the fullest possible extent what the historical moment allows. Taking into account the fact that economic ties in an objective social reality are extremely dynamic and 
subject to a variety of influences, it cannot be determined that the exchange rate regime would be optimal over a longer period. For countries in transition (Serbia), it is essential to maintaining the stability of the exchange rate policy that takes place under the control of the National bank that it is adapted to conditions of the economy. Insisting on the use of a flexible exchange rate, which is the inherent economy of developed countries in the region, can be accompanied by numerous controversies if in the country there is not a sufficient degree of creating institutional and market structures. A flexible exchange rate regime shows greater ability to adapt to changes in real and logical system components of the monetary law caused by shocks and provides a greater degree of independence of monetary policy, which is what in practice the National bank with its interventions in the period of the past 15 years has been trying to achieve.

The legal framework of governing public debt in Serbia is defined by the provisions of the Law on budget system, the Law on public debt, as well as the Public Debt Management Strategy (from 2013-2016) and the Memorandum of the budget in economic and financial policy (for the year 2014 with projection for the years 2015 and 2016). Depending on the current state of debt and repayment projections, it is expected that in the coming period, a year receives 800 million euros, which are necessary for servicing debt equally spaced in the period of the 2011-2016 years, and the most significant individual commitment is paying off the old foreign currency savings, which is due for payment by the end of the year 2016. The procedure for the adoption of strategy in domestic monetary law is similar to a methodology that exists in parallel legislature. So, the Finance Minister manages the public debt and preparing the strategy that is delivered to the Government for approval on a yearly basis. The strategy is an integral part of the Memorandum on the budget and economic and fiscal policy for the observed budget year and the following two fiscal years.

During creating the mid-term strategy of public debt, analysis of costs and risks based on different projections is used. The so-called basic scenario, which refers to conditions that dictate the return of public debt, refers to the tracking of changes to exchange rates, reference interest rates and reference interest rates in foreign markets. ${ }^{26} \mathrm{In}$ addition to defining the basic scenario, four additional scenarios are provided, adapted for possible macroeconomic shocks and shocks in the primary budget. In cooperation with experts from the World Bank, the management of the public debt has applied the Medium term debt strategy model (MTDS) for the purpose of more efficient management of public debt. On this occasion, it has identified alternative strategies for financing related to the financing of public debt through the emission of euro-bonds (on a different time limit) and additional emissions of government securities in dinars. The policy of public debt management is adopted for a longer period, but it must not be forgotten that the decisions on the financing of the budget expenditures are brought annually in the frame of budget law.

Factors that complicate the implementation of the strategy are related to the (in)stability of the macro-economic situation in the country in terms of efficient tax collection, levels of unemployment, inflation, exchange rate, flow in the world economy, foreign trade partners and the achieved degree of fiscal decentralisation (possibility of borrowing from local levels of government). In terms of the global financial crisis, public debt represents a significant source of financing public expenditures. In conditions when the state is unable to provide enough budgetary funds for financing public spending because there is no possibility of increasing the tax rate or the introduction of new tax forms (due to 
reaching the absolute tax limit), fiscal revenues ceded in place of non-fiscal public revenues of which public loan is the most significant (as the dominant form of public debt in modern economies). The dangers of an excessive public loan of a sector by domestic legislation impose certain limitations in the form of fiscal rules, which is ratio legis timely fulfillment of overdue financial obligations as a debtor. The author's opinion is that violation of fiscal rules should result in stricter legal sanctions with the clearly defined fiscal responsibility of competent authority for their non-compliance, in order to avoid the consequences, such as bankruptcy or moratorium of states in terms of restoring the public debt. Public debt management policy must be seen as a part of economic policy which has special legal measures and instruments, rather than as an integral part of the fiscal (or monetary) policy as it has traditionally been considered in the financial literature. In creating the optimal policy of public debt management, special attention must be paid to the phenomenon of tax competition and the need for fiscal sustainability, which indicates a major challenge for all countries in transition. Also, a clearly defined and transparent strategy for rolling back public debt as the most significant system of legal act (in addition to the law on public debt and the law on budget) must be functionally consistent with the objectives of fiscal policy and monetary policy in order to achieve the desired macroeconomic objectives in terms of market stability. A significant role in the process of European standards and solutions could potentially carry out national courts and special state bodies dealing with the issue of implementation control and spending of budget funds.

The role of national courts in the assessment of respecting fiscal rules is determined by the existence of expert knowledge and qualifications that currently do not exist in the local court system, but it does not mean that efforts towards the institutionalization of such jurisdictions do not need to continue. A positive example in this aspect represents a notice of legislators in the formation of specialized court departments, which will deal with the issue of financial crime, which can indirectly can achieve the effect of the tightening of fiscal discipline. A big disadvantage in domestic law is the absence of specialized courts of auditors, which would have dealt with the issue of liability of bookkeepers and employees for management and spending of budgetary funds.

The main problem is that in most cases initiated there has been no clear determination of responsibility for the spending of budgetary funds and there is an unspecified legal effect of its opinions, recommendations and guidelines with regard to compulsory treatment. When it comes to public debt management policies, the monetary legislator has determined the principle of soft budgeting by the law on the National Bank of Serbia, where article 62 specifically prohibits all forms of monetization of debt, or lending of the government and covering the budget deficit. With regard to all EU members and before the outbreak of the global financial crisis, there was trouble in maintaining the stability of the public debt, the task of domestic subjects monetary law (the National bank and the Directorate for public debt primarily). In this field the most complex works require a lot of respect for the solutions set out by the new economic measures of economic governance in the eurozone and in the introduction of the brake for debt and golden rules of the budget. Taking into account that Serbia, as a successor to the former state, inherited the biggest part of the public debt, constructive measures must be taken in order to reduce its height to $60 \%$ of GDP. The main measures, which must be taken, cannot only include measures of saving set out by the ongoing economic recovery plan but they also require increasing the size and the structure of production and the influx of foreign investment, as the preconditions of economic growth and development. It is possible to achieve this by applying certain incentives for foreign capital investment particularly in underdeveloped areas, which are implemented and the 
objectives of regional development policy, but that must not make discrimination against domestic executives by giving disproportionately large privileges to foreign economic entities.

\section{CONCLUSION}

It is clear that for Serbian monetary lawmakers on the road to euro-integration there are big challenges, which, although complex, are not insurmountable if a credible relationship between the competent state institutions and associations of citizens is established with clearly defined responsibilities for achieving the economic and legal benefits that membership brings. Although, the process of economic integration implies a limitation of some components of the monetary, fiscal and financial sovereignty, it is not supposed to mean that the state on the path of European integration is completely subordinate to national interests of supranational requirements, taking into account the recent experiences of members of the Union during the debt crisis and the failure to maintain the stability of the eurozone. Convergence of domestic monetary system, with values set out with general and specific mechanisms of coordination of economic policy in the EU, cannot have the form of sui generis, because the same path had to pass all the smaller state members of the Union, leaving aside the experience of leading countries such as France and Germany in the field of coordination of fiscal policies. Certainly, this does not mean that a local path should be fully deprived of respect and protection of national interests and values. It is my opinion that Serbian legislators on the path of economic and monetary integrations enjoy (in conditional terms) certain qualitative advantages that other member states did not have and which are reflected in the capability of comprehensive and critical analysis of decades of results in the process of formatting a European monetary law (starting from the founding of the European economic community, through the formation of EMU to considering ideas of introducing the concept of banking and fiscal union). In this process of political learning from somebody else's mistakes and selection of the best practice we can see the instruments for the monetary system harmonization in a way that is not only economically efficient and an effective, but also legally legitimate and politically justified.

\section{LITERATURE}

Babić, B., 'Pravna strana krize u Evropskoj monetarnoj uniji' (Legal Aspect of the Crisis in the European Monetary Union) (2011) 48 Pravo i privreda (Law and Economy) 420-35.

Cerovac, M. et al., Evropska Unija (The European Union) (1st edn, Mate Zagreb 2010).

De Grauwe, P., Economics of Monetary Union (7th edn, Oxford University Press 2003).

De Lapasse, P., 'The Legal Status of the Euro' in Legal Aspects of the European System of Central Banks - Liber Amicorum Paolo Zamboni Garavelli (European Central Bank 2005) 235-43.

Dutzler, B. \& Hable, A., 'The European Court of Justice and the Stability and Growth Pact: Just the Beginning' (2005) European Integration online Papers 9/5.

Feibelman, A., 'Europe and Future of International Monetary Law' (2012) 22/1 Transnational Law and Contemporary Problems 101-04.

Feldstein, M., 'Coordination in the European Union' (2013) Working Paper No. 18672 The National Bureau of Economic Research.

Giovanoli, M., 'A New Architecture for Global Financial Market: Legal Aspects of International Financial Standards Setting' in Giovanoli, M. (ed), The International Monetary Law: Issues for the New Millenium (Oxford University Press 2000) 3-59.

Gianviti, F., 'Current Legal Aspects of Monetary Sovereignty' (2005) 4 IMF Current Developments in Monetary and Financial Law 3-16. 
Golubović, S., Evropska monetarna unija-Institucionalni aspekti (European Monetary Union: Institutional Aspects) (Centar za publikacije Pravnog fakulteta u Nišu/Centre for Publication of Faculty of Law Niš 2007).

Herrmann, C., 'Legal Aspects of the European Sovereign Debt Crisis' (2013) 41/1 Hitotsubashi Journal of Law and Politics 26-40.

Jovanović, M., Evropska ekonomska integracija (European Economic Integration) (Ekonomski fakultet Beograd / Belgrade Faculty of Economy 2007).

Krugman, P., 'What do We Need to Know about the International Monetary System?' in Essays in International Finance No. 190 (Princeton International Finance Section 1993) 1-32.

Lastra, M.R., Legal Foundations of International Monetary Stability (Oxford University Press 2007).

Lastra, M.R., International Financial and Monetary Law (Oxford University Press 2015).

Louis, V.J., 'The New Monetary Law of European Union' in Giovanoli M. (ed), International Monetary Law: Issues for the New Millennium (Oxford University Press 2000) 137-60.

Mortensen, J., 'Economic Policy Coordination in the EMU: From Maastricht via SCP to the Fiscal Pact' (2013) 459 CASE Network Studies \& Analyses 1-22.

Mundell, R., 'A Theory of Optimum Currency Areas' (1961) 51/4 American Economic Review $657-65$.

Prokopijević, M., Evropska monetarna unija (European Monetary Union) (Beograd Gradjevinska knjiga / Belgrade Construction Book 2007).

Schaechter, A., Kinda, T., Budina, N., Weber, A., 'Fiscal Rules in Response to the Crisis Toward the Next-Generation Rules' (2012) A New Dataset IMF Working Papers WP12/8/175.

Siekmann, H., 'Law and Economics of Monetary Union' (2011) Institute for Monetary and Financial Stability WP Series No. 45.

Wahlig, B., 'European Monetary Law: The Transition to the Euro and the Scope of Lex Monetae' in Giovanoli M. (ed), International Monetary Law: Issues for the New Millennium (Oxford University Press 2000) 21-136. 